\title{
Surface fuel accumulation and decomposition in old-growth pine-mixed conifer forests, northwestern Mexico
}

\author{
Danny L. Fry ${ }^{1 *}$, Jens T. Stevens ${ }^{1}$, Andrew T. Potter ${ }^{1}$, Brandon M. Collins ${ }^{2}$ and Scott L. Stephens ${ }^{1}$
}

\begin{abstract}
Background: Stand-level forest structure varies spatially and surface fuels would be expected to vary as well. We measured surface fuel deposition and decomposition within old-growth Jeffery pine (Pinus jeffreyi Balf.)-mixed conifer forests to quantify rates of change and examine relationships with overstory structure and composition.
\end{abstract}

Results: Annual fuel deposition ranged from 0.7 to $20.1 \mathrm{Mg} \mathrm{ha}^{-1}$ for litter and 0.2 to $0.8 \mathrm{Mg} \mathrm{ha}^{-1}$ for woody fuels, exhibiting large temporal and spatial variation, and corresponded with annual precipitation during the study period. Surface fuel deposition had high spatial heterogeneity and was predicted by stand structure such as basal area and canopy cover, particularly for litter deposition, which was the main contributor to total fuel loadings in this system. Jeffery pine litter decomposition rate of 7 to $11 \% \mathrm{yr}^{-1}$ over the six-year study period is among the lowest compared to other conifer forests in western North America.

Conclusions: Two sites were distinguished by edaphic and structural characteristics, but exhibited similarities in fuels dynamics. Incorporating within-stand variation into fuel modeling could improve the accuracy in predicting fire behavior, fire effects, and stand progression.

Keywords: Baja California, downed wood, forest litter, forest structure, needle decay, Sierra Nevada, Sierra San Pedro Mártir

\footnotetext{
* Correspondence: firefrysurf@gmail.com

${ }^{1}$ Department of Environmental Science, Policy, and Management, University

of California, 137 Mulford Hall, Berkeley, California 94720-3114, USA

Full list of author information is available at the end of the article
} 


\section{Resumen}

Antecedentes: La estructura forestal a nivel de rodal varía espacialmente y podría esperarse que los combustibles vegetales superficiales también varíen. Medimos la deposición y descomposición del combustible superficial dentro de un bosque mixto maduro de pino de Jeffrey (Pinus jeffreyi Balf.) y otras coníferas para cuantificar las tasas de cambio y examinar sus relaciones con la estructura y composición del dosel.

Resultados: La aporte anual de combustible varió entre 0,7 a 20,1 $\mathrm{Mg} \mathrm{ha}^{-1}$ para la hojarasca y entre 0,2 a 0,8 $\mathrm{Mg} \mathrm{ha}^{-1}$ para combustibles leñosos, exhibiendo una gran variación espacial y temporal que se correspondió con la precipitaciones anuales durante el período de estudio. La deposición de combustible superficial tuvo una gran heterogeneidad espacial y fue predicha por la estructura del dosel como el área basal y la cobertura del dosel, particularmente la deposición de la hojarasca (acículas), la cual fue la que más contribuyó a la carga total de combustible en este sistema. La tasa de descomposición de la hojarasca del pino de Jeffrey de 7 al $11 \%$ anual en los seis años que duró el período de estudio está entre las menores comparada con otros bosques de coníferas en el oeste de Norte América.

Conclusiones: Dos sitios fueron diferenciados por sus características edáficas y estructurales, aunque exhibieron características similares en la dinámica de sus combustibles. La incorporación de la variación intra-rodal en el modelado de combustibles puede mejorar la exactitud en la predicción del comportamiento del fuego, en sus efectos y en la evolución del rodal.

\section{Introduction}

Downed woody fuels are fundamental components of forests throughout the world and contribute to diverse ecosystem services and processes such as wildlife habitat, wildland fire, and nutrient cycling. With the current emphasis on improving forest resilience in US forests, land managers are under increasing pressure to deal with unnaturally high accumulations of fuels that have resulted from logging activities or years of fire suppression, especially in forests adapted to frequent, low- to moderate-intensity fire regimes (Stephens et al. 2010).

Downed woody fuels (surface fuels) commonly have a heterogeneous distribution across the forest floor (Fry and Stephens 2010, Lydersen et al. 2015). Fuel accumulation is influenced by annual variation in moisture availability through is impacts on tree growth, as well as by abrupt events such as tree mortality and storms. Although the importance of surface fuels is widely recognized, quantifying surface fuel loads can often be challenging due to their high spatial and temporal variability (Keane et al. 2012a, Keane 2013, Lydersen et al. 2015). Fuels transects (Brown 1974) are an accurate method for estimating surface fuel loads, but they tend to be time-consuming and expensive, making it difficult to cover large areas (Arroyo et al. 2008).

In addition to their importance when modeling fire behavior, surface fuels including deposited foliage, large downed wood, and branch fragments are important components of ecosystem dynamics models (Keane et al. 1996). Although cones are currently not classified as fuels in the fire behavior and danger rating systems in the USA, they are important indicators of fire adaptations and are used in ecosystem models (Fonda and Varner 2004).
Researchers have worked to quantify fuel dynamics in Sierra Nevada forests for several decades (van Wagtendonk 1985; van Wagtendonk et al. 1996, 1998a, 1998b; van Wagtendonk and Moore 2010). For instance, Agee et al. (1977) quantified fuel deposition in monotypic stands of white fir (Abies concolor [Gord. \& Glenf.] Lindl. ex Hildebr), ponderosa pine (Pinus ponderosa Laws.), sugar pine (P. lambernania Douglas), and giant sequoia (Sequoiadendron giganteum [Lindl.] J. Buchholz). In mixed conifer stands in the southern Sierra Nevada, USA, Keifer et al. (2006) found that fuels accumulated to 84 to $88 \%$ of pre-fire levels 10 years after prescribed fire; in similar stands in the central Sierra Nevada (Yosemite National Park, California, USA), they found that fuels accumulated to 150 to $180 \%$ of pre-fire values after 31 years. Stohlgren (1988) conducted a four-year study in two mixed stands and found that deposition rates did not correlate well with stand-level forest structure and speculated that deposition might better be related to individual tree basal area and the ratio between tree height and crown height. Keane (2008) studied deposition and decomposition rates for major forest types of the northern Rocky Mountains, USA; forest species investigated included ponderosa pine, lodgepole pine (Pinus contorta Douglas ex Loudon), and whitebark pine ( $P$. albicaulis Engelm.). He related the annual rates of fuels accumulation to environmental and vegetation variables and found that deposition was best estimated by leaf area index, stand basal area, and tree height.

Most of these previous studies have explored the relationship between forest overstory and fuel bed characteristics. It is less common for studies to quantify within-stand variation in fuel accumulation and decomposition rates, and how these rates may be influenced by overstory 
structure and composition (Lydersen et al. 2015). These patterns can be difficult to infer, as components of surface fuels vary at different scales (Fry and Stephens 2010, Keane et al. 2012a) and loads of different size classes are generally uncorrelated (Brown and Bevins 1986, Keane et al. 2012b). New information is needed to provide better estimates of the variability in fuel loads on smaller spatial scales (Ottmar et al. 2012), especially in old-growth forests for which past management actions such as fire suppression and harvesting could mask important fuel relationships at finer scales. In particular, quantification of surface fuel deposition and decomposition rates in forests that have not been severely impacted by fire-suppression and harvesting are critical to provide reference conditions that can be used to manage surface fuels in mixed-conifer forests that are currently outside their range of historical variability (Safford and Stevens 2017).

The Jeffrey pine (Pinus jeffreyi Balf.)-mixed conifer forests of the Sierra San Pedro Mártir (SSPM), northwestern Mexico, offer an opportunity to investigate surface fuel dynamics that are more characteristic of the historical range of variation in frequent-fire mixed-conifer forests due to the absence of past logging and systematic twentieth century fire suppression (Stephens et al. 2008). The objectives of this study were, therefore, to quantify variability in surface fuels and to explore potential relationships with overstory structure in an old-growth Jeffrey pine-mixed conifer forest. Specifically, we addressed the following questions:

1) What are the deposition and decomposition rate of litter and woody fuels?

2) How do these rates vary with overstory forest structure?

3) Do the rates vary by year and by sites that differ in soil type and species composition?

Information from this study may serve multiple purposes including refining objectives for fire management plans and restoration treatments, understanding fuel load-stand structure relationships, and improving fuel model classifications. This information would be most applicable to Jeffrey pine and xeric mixed-conifer forests of California and Nevada, USA, from the east side of the southern Cascade Mountains through the Sierra Nevada into the Transverse and Peninsular ranges in California (Rivera-Huerta et al. 2015, Dunbar-Irwin and Safford 2016, van Wagtendonk et al. 2018). However, information from this study could be applicable to other mediterranean-climate, pine-dominated forests that once experienced frequent, low- to moderate-intensity fire regimes.

\section{Methods}

\section{Study area}

The study sites are located in the SSPM National Park $\left(31^{\circ} 37^{\prime} \mathrm{N}, 115^{\circ} 59^{\prime} \mathrm{W}\right)$ in north-central Baja California, approximately $100 \mathrm{~km}$ southeast of Ensenada, Mexico (Fig. 1). This area is identified as being in the North American mediterranean-climate zone (Minnich et al. 2000), although fire seasonality would suggest that the North American Monsoon System also influences this region (Skinner et al. 2008). There is no long-term weather information from the SSPM study area; average annual precipitation measured near our research sites $(<5 \mathrm{~km})$ with temporary weather stations on the northern plateau (2400 m elevation; 1989 to 1992) was $55 \mathrm{~cm}$ (Minnich et al. 2000). Climate data for the duration of the study is provided in Fig. 2 and is from the Potrero Remote Accessed Weather Station (NWS ID 045730), San Diego County, California, USA. We did not use weather data from the SSPM the temporal depth (length of record) was too short and they did not record snowfall (Dunbar-Irwin and Safford 2016).

Jeffrey pine dominates the conifer forests in the SSPM (Minnich et al. 2000). We quantified stand structure using two 4 ha stem maps from Fry et al. (2014). The SSPM granitic site (GRAN) is edaphically and structurally similar to portions of the eastern Sierra Nevada, Lake Tahoe Basin, and southern California mountains (Minnich et al. 1995, Stephens 2001, Barbour et al. 2002, Taylor 2004, Dunbar-Irwin and Safford 2016, van Wagtendonk et al. 2018; Fig. 2). Soils are shallow, well to excessively drained, and relatively acidic (Stephens and Gill 2005); chemical and textural properties are similar to typical granite-derived soils in comparable forests in California (Potter 1998). The SSPM metamorphic site (META), approximately $2 \mathrm{~km}$ north of GRAN, is a monotypic stand of Jeffrey pine with an understory of canyon oak (Quercus chrysolepis Liebm.) and peninsular oak (Quercus peninsularis Trel.). Soils are shallow and parent material is metamorphic quartz schist (R. Taskey, California Polytechnic State University, San Luis Obispo, California, USA, personal communication).

Fire is an important ecological process in Jeffrey pine-mixed conifer forests (Taylor 2004, North et al. 2009a), and occurred relatively frequently prior to the Park's recent efforts at suppressing fires, with median fire return intervals of 5 to $13 \mathrm{yr}$, depending on the composite filter (Stephens et al. 2003). Road construction and limited summer and fall fire suppression efforts have increased fire intervals in most areas of the forest beginning in the early 1970s (Skinner et al. 2008). According to the fire-scar record, the last large wildfire was in 1946; smaller fires occurred in 1980 and 1962 at GRAN and META, respectively (Stephens et al. 2003). The SSPM has not been harvested for timber except for one 10 ha area that had overstory trees removed that is not near our research sites, although there is a history of livestock grazing at varying intensities, commencing in the late eighteenth century, to support the San Pedro 


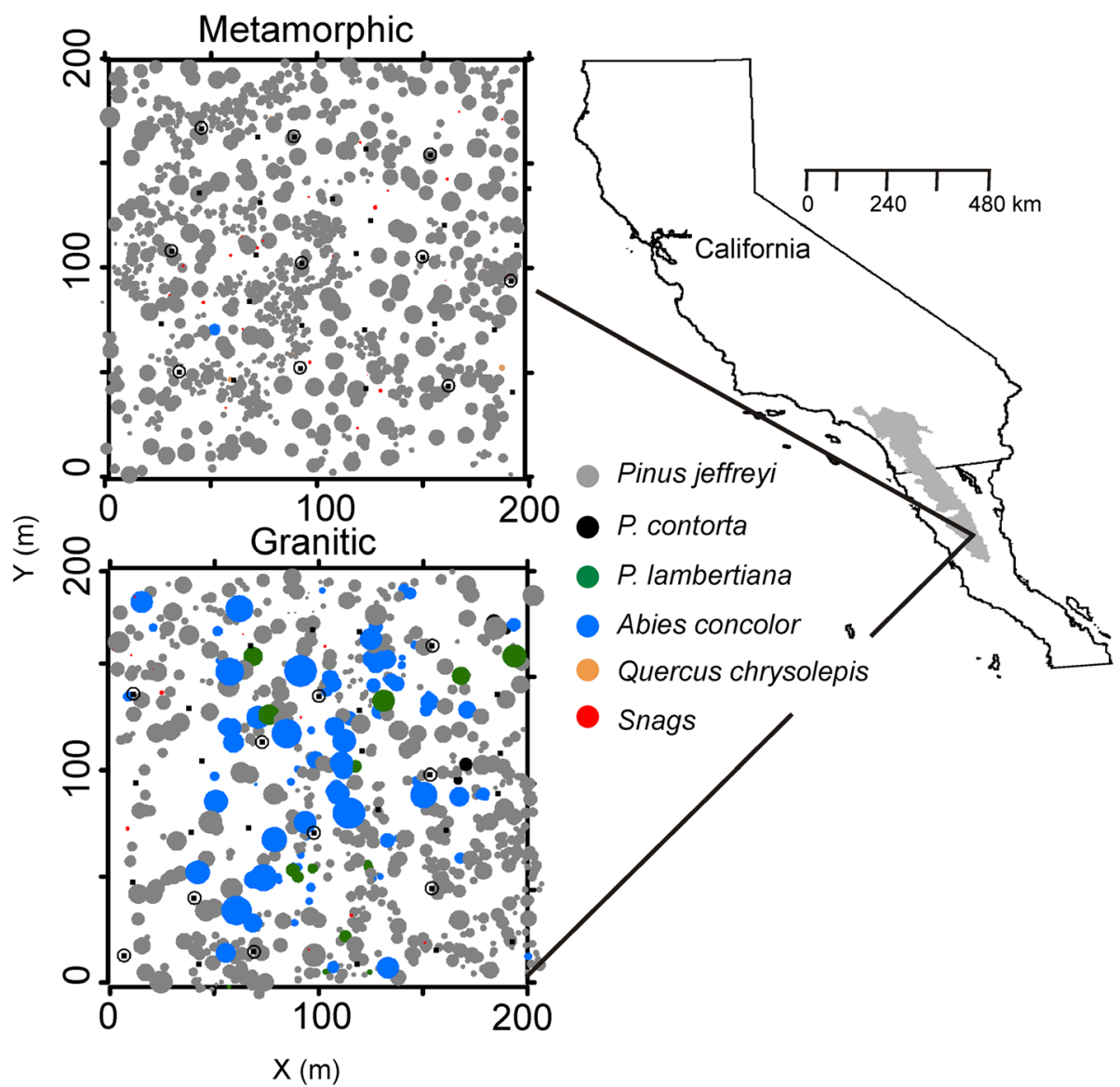

Fig. 1 Locations of all trees (diameters $>5 \mathrm{~cm}$ ) in 4 ha stem maps in old-growth Jeffrey pine-mixed conifer forests. Woody fuels (black open circles) and litter and fine woody fuels (squares) were collected annually from 2010 to 2013. Sites are within the Sierra San Pedro Mártir National Park in the Peninsular Range (gray shading), northwestern Mexico.

Mártir Mission (Minnich and Franco 1998, Stephens et al. 2003).

\section{Plot selection and mapping}

At both sites, we used a 4 ha stem map on a uniform slope aspect and soils to describe forest spatial patterns and measure surface fuels. This scale included 1000 to 1500 trees, incorporating most of the stand-level spatial heterogeneity (Fry and Stephens 2010, Fry et al. 2014). In pine-dominated forests that once experienced frequent, low- to moderate-intensity fires, tree regeneration occurred in small openings (Stephens and Fry 2005,
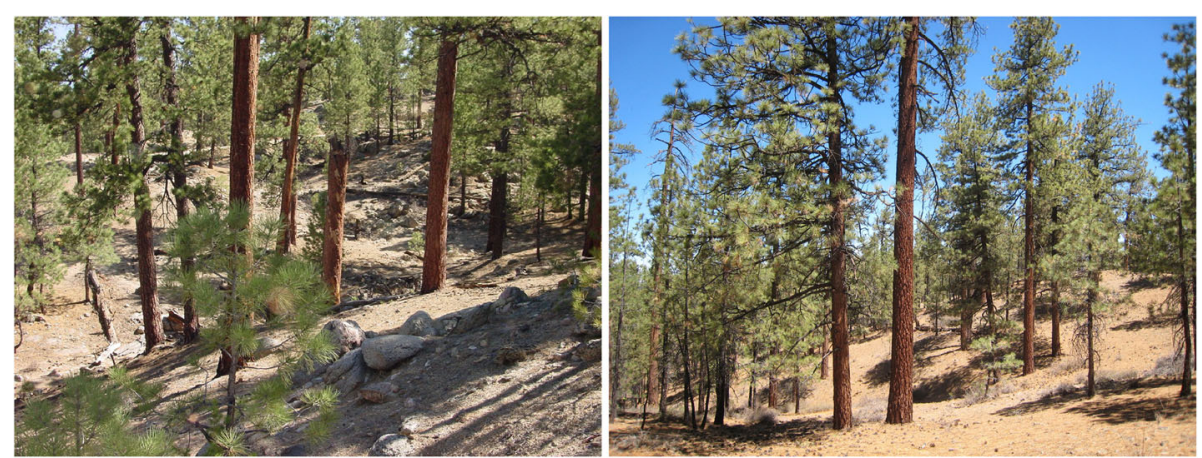

Fig. 2 Stand structural characteristics of the two sites, GRAN (left) and META (right), in the Sierra San Pedro Mártir National Park, Mexico. Photos by S. Stephens. 
Larson and Churchill 2012), which were likely created by fine-scale canopy disturbances caused by fire, insects, disease, windthrow, or drought (Boyden et al. 2005). Using a grid of monument posts established within both 4 ha areas, we collected GPS coordinates and recorded species, status, diameter at breast height (DBH), and tree height and height to live crown base (live trees only) for every tree with $\mathrm{DBH}>5 \mathrm{~cm}$ (Fig. 1). We used the stem map information in Spatial Analyst tool in ArcGIS v10 (ESRI, Redlands, California, USA) to calculate the total percent canopy cover, canopy cover by species, total basal area, and basal area by species for a 0.01 ha circular plot centered on surface-fuels measurement plots. We used this plot size to avoid multiple plots sampling the same tree. Overstory canopy cover was calculated using crown radius for each tree using species-specific allometric equations from Bechtold (2004) (see Fry et al. 2014 for description of canopy cover calculations).

\section{Soil sampling and analysis at SSPM-META}

We collected soils from the grid of monument posts at the META site, similar to previous work on the GRAN site (see Stephens and Gill 2005). Separated by approximately $25 \mathrm{~m}$, each of the 27 soil samples were collected at a depth of 5 to $8 \mathrm{~cm}$. Soil samples were sieved to $<2 \mathrm{~mm}$ and coarse fragment content was determined on a weight basis. The air-dried moisture content was determined and all future measurements were corrected for soil moisture and were based on oven-dry weight. Particle size analysis was determined by the hydrometer method (Gee and Bauder 1986). Soil pH was determined in a 1:2 soil-to-solution mixture of $0.01 \mathrm{M} \mathrm{CaCl}_{2}$ (Kalra and Maynard 1991) using a glass electrode $\mathrm{pH}$ meter (Accumet 15, Fisher Scientific Hampton, New Hampshire, USA). Cation exchange capacity (CEC) was determined by the ammonium acetate ( $\mathrm{pH} 7$ ) method (Sumner and Miller 1996) and exchangeable bases in the ammonium acetate leachate were measured by atomic absorption spectrometry. Available phosphorus was determined by the Bray 1 (dilute acid-fluoride) method and a colorimeter. A subsample of each soil was ground in a ball mill to pass 60-mesh screen for total carbon and nitrogen determination by combustion gas analyzer (Kalra and Maynard 1991).

\section{Fuel deposition and decomposition}

Using the GPS-based monument posts that were used to develop the stem maps (Fry et al. 2014), we selected 30 posts (plots) that were systematically distributed throughout the area at each site to measure surface fuel deposition and decomposition. Mean distance between adjacent plots was $27 \mathrm{~m}(\mathrm{SD} \pm 2.6 \mathrm{~m})$. We installed $0.12 \mathrm{~m}^{2}$ wire collection baskets (mesh opening of $2 \mathrm{~cm}^{2}$ ) to intercept fuels. This mesh size appeared sufficient for collecting canopy fuels, including male cones and white fir needles. At 10 of these plots, we measured woody fuels deposition by measuring material that fell within a $3 \mathrm{~m}$ radius $\left(28.3 \mathrm{~m}^{2}\right)$ area centered on plot center. Upon establishment, we removed all woody fuels from the immediate area and collected and measured accumulated fuels every year, between the last week in May to the first week in June from 2010 to 2013, replacing baskets disturbed by wildlife or fallen trees and branches.

We sorted all woody fuels by size class and type: 1-hour ( 0 to $0.6 \mathrm{~cm}$ branch diameter), 10-hour (0.6 to $2.5 \mathrm{~cm}$ ), and 100-hour (2.5 to $7.6 \mathrm{~cm}$ ), female cones (separated by current year's drop [brown] and greater than one year old [grey]), needles, and other (i.e., male cones, bark, cone scales, and hardwood leaves). All fuels were weighed in the field, and a subsample of each category was transported to the laboratory, oven dried at $100{ }^{\circ} \mathrm{C}$ for 24 hours, and weighed. We used the ratio of dry weight to wet weight of the subsampled fuels to calculate moisture content of each fuel class. Our values were similar to the previously established estimates of 4 , 6 , and $8 \%$ moisture content for 1-, 10-, and 100-hour fuels, respectively, so we used these values to derive the dry weight of all fuels (Stephens 1998). For analytic purposes, we considered litter as 1-hour fuels and cones as 10-hour fuels.

At these same 10 plots, we used litter bags to estimate the rate of decay for Jeffrey pine needles. The bags, made of nylon window screen (about $225 \mathrm{~cm}^{2}$ ) with a mesh size of about $2 \mathrm{~mm}$, sewn closed with fishing line, held a field-measured 50 grams of recently dead needles collected from nearby live trees. We laid the five litter bags on the forest floor near the litter baskets, and then anchored them to the plot post. Bags were installed in 2009 and collected at the same time as described above in 2010, 2011, and 2015. Decomposition was measured over six years by collecting one bag from each plot, drying in an oven at $50{ }^{\circ} \mathrm{C}$ for 24 hours, then calculating weight prior to submitting a subsample for chemical analysis at a soil processing lab.

\section{Analyses}

For all surface fuels, soil characteristics, and pine needle decay, we summarized mean plot-level values by year and site. To determine the potential for spatial dependence, we tested each variable for spatial autocorrelation using Moran's $I$ test (Moran 1950). Moran's $I$ is a weighted correlation coefficient that detects departures from spatial randomness, and ranges from +1 (positive correlation) to -1 (negative correlation). For surface fuels, we examined how a set of variables varied among sites, years, and with forest structural characteristics (plot-level canopy cover, basal area, and tree density). The surface fuel variables $\left(\mathrm{Mg} \mathrm{ha}^{-1}\right)$ tested included total 
Table 1 Forest structural attributes (trees with diameter $>5 \mathrm{~cm}$ inside the 0.01 ha circular plots) for fuels deposition plots in old-growth Jeffrey pine-mixed conifer forests in Sierra San Pedro Mártir National Park, northwestern Mexico. GRAN = granitic site, META = metamorphic site, SD = standard deviation of the mean $(n=10)$.

\begin{tabular}{llrr}
\hline Site & Structural variable & Mean & SD \\
\hline GRAN & Canopy cover $(\%)$ & 32.1 & 3.6 \\
& Mean diameter $(\mathrm{cm})$ & 33.7 & 0.8 \\
& Live basal area $\left(\mathrm{m}^{2} \mathrm{ha}^{-1}\right)$ & 21.9 & 4.5 \\
& Live density $\left(\right.$ trees $\left.\mathrm{ha}^{-1}\right)$ & 196.7 & 34.1 \\
META & Snag density & 0.0 & \\
& Canopy cover $(\%)$ & 29.2 & 4.4 \\
& Mean diameter $(\mathrm{cm})$ & 22.5 & 1.8 \\
& Live basal area $\left(\mathrm{m}^{2} \mathrm{ha}^{-1}\right)$ & 21.9 & 4.8 \\
& Live density $\left(\right.$ trees ha $\left.^{-1}\right)$ & 336.7 & 82.7 \\
& Snag basal area $\left(\mathrm{m}^{2} \mathrm{ha}^{-1}\right)$ & 2.5 & 1.8 \\
& Snag density $\left(\mathrm{trees} \mathrm{ha}^{-1}\right)$ & 10.0 & 5.6 \\
\hline
\end{tabular}

weight in litter basket; litter weight in the litter basket; total fuel weight on the surface plots; total cone weight on surface plots; and 1-hour, 10-hour, and 100-hour fuels on the surface plots. All response variables were normalized using a square root function. We collected data on 1-, 10- and 100-hour fuel loads within the litter baskets, but these data were highly zero-inflated and skewed by a few plots in which woody fuels happened to fall within the baskets, so we did not analyze these variables. Total fuel loads in baskets across our study sites were primarily driven by litter accumulation rather than woody fuels.

We tested for a significant effect of site (GRAN versus META) on total fuel loads in both baskets and on surface plots, for each year, using a simple linear mixed-effects model,

$$
y=B * \text { site }+(1 \mid \text { year })+E
$$

where $y$ is the response variable of interest (basket- or plot-based surface fuel load), $B$ is the fixed effect of site, and (1|year) is a random intercept for year, allowing for total fuel loads to vary among years, and $E$ is the random error assumed to be independently distributed with a normal distribution. We found no significant effect of site on any surface fuel variable, so for subsequent analysis of forest structure effects, we combined the two sites. We tested the effects of local canopy cover, basal area, and tree density ( 0.01 ha circular plots) on the surface fuel variables described above, using a simple linear model in which each year was analyzed separately.

To compare the change in pine needle weight over time, we used the exponential decay function $(e)$, which quantifies decay of organic material for longer decay processes, and the parameter $k$ may be used to compare decay rates (Keane 2008),

$$
\frac{A_{\mathrm{t}}}{A_{0}}=e^{-k t}
$$

where $A$ is the amount of material at time zero $\left(A_{0}\right)$ and at time $t\left(A_{\mathrm{t}}\right)$. We fit a curve defined above to each plot with at least three data points (initial and two subsequent measurements) using non-linear least squares estimation in $\mathrm{R}$ ( $\mathrm{R}$ Development Core Team 2014). The fitted value of $k$ can therefore be used to calculate the percent change in needle decay between any two given years, and to compare decomposition in the SSPM to other studies that have also calculated $k$ within different systems. Initial values of needle weight were determined by sampling recently dead needle material from 5 trees per site in 2009 .

We modeled variation in decay rate $k$ as a function of site, using the $k$ parameter value calculated for each plot across the six years, using a simple linear model. As site did not have a significant effect on $k$ (see Results), we pooled both sites and tested for effects of forest structure on decomposition rate using a simple linear model of $k$ conditional on canopy cover, basal area, and density.

\section{Results}

Forest structure and soils

For both sites, average canopy cover was below 33\% (Table 1), with 10 of the 60 plots occurring within

Table 2 Chemical and physical soil characteristics from an old-growth Jeffrey pine forest on metamorphic soils in the Sierra San Pedro Mártir, northwestern Mexico. $\mathrm{N}=$ nitrogen (percent total), $\mathrm{C}=$ carbon (percent total), $\mathrm{P}=$ phosphorus, CEC = cation exchange capacity, $\mathrm{Ca}=$ calcium, $\mathrm{Mg}=$ magnesium, $\mathrm{K}=$ potassium, $\mathrm{Na}=$ sodium, $\mathrm{SD}=$ standard deviation of the mean. Asterisk $\left({ }^{*}\right)$ indicates significant difference $(P<0.05)$ from a nearby old-growth Jeffery pine-mixed conifer site on granitic soils (see Stephens and Gill 2005).

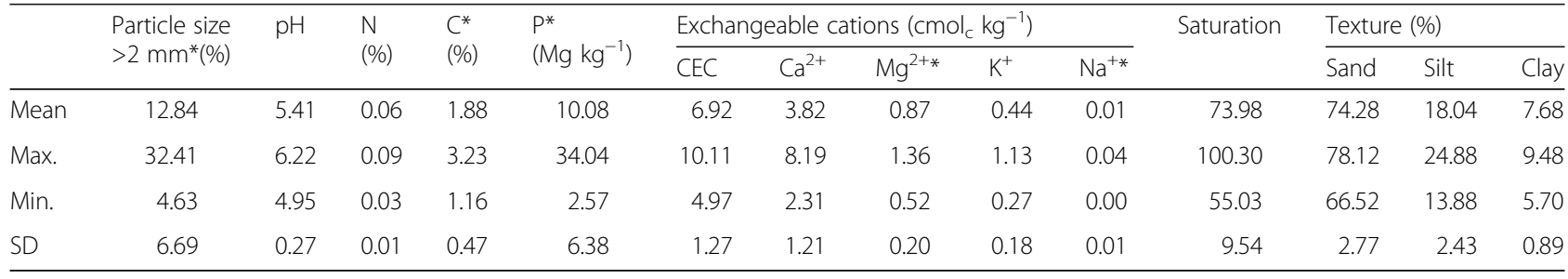




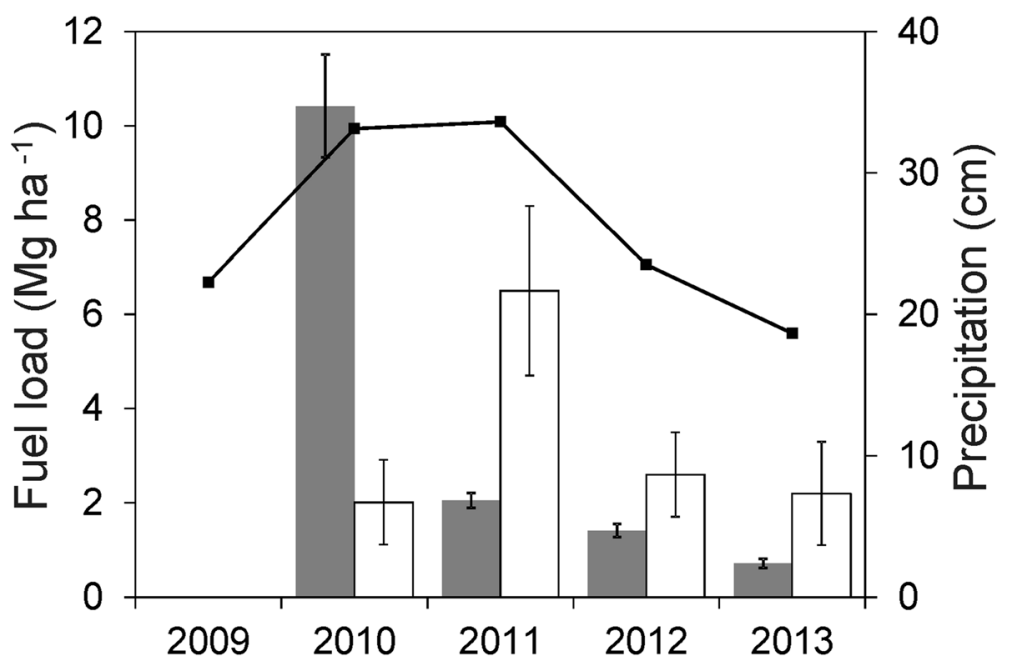

Fig. 3 Annual precipitation (cm; line) measured at the southern-most California Remote Access Weather Station (Potereo RAWS) by mean annual surface fuels collected in litter baskets (gray bars; $\mathrm{Mg} \mathrm{ha}^{-1}$ ) and surface plots (white bars; $\mathrm{Mg} \mathrm{ha}^{-1} \times 10^{1}$ ). Error bars show standard error or the mean. Precipitation is summarized by season (i.e., total precipitation in 2009 is from June 2008 through May 2009) to correspond with collections.

Table 3 Surface fuels (mean with standard deviation in parentheses; Mg ha ${ }^{-1} \times 10^{2}$ ) collected annually from litter baskets and surface plots in old-growth Jeffrey pine-mixed conifer forests in northwestern Mexico. "Other" includes male cones, oak leaves, bark, and cone scales in baskets, and female cones in plots. GRAN = granitic site, META = metamorphic site.

\begin{tabular}{|c|c|c|c|c|c|c|c|}
\hline Type & Site & Year & Litter & 1-hour & 10-hour & 100-hour & Other \\
\hline \multirow[t]{4}{*}{ Basket } & GRAN & 2010 & $68.4(7.5)$ & $5.1(2.7)$ & $27.8(16.9)$ & $1925.6(1892.1)$ & 49.7 (13.5) \\
\hline & & 2011 & $145.5(18.4)$ & $1.5(0.8)$ & $10.7(5.3)$ & 0.0 & $30.1(7.3)$ \\
\hline & & 2012 & $103.6(11.2)$ & $8.8(4.9)$ & $10.6(10.2)$ & 0.0 & $41.1(7.0)$ \\
\hline & & 2013 & $59.1(6.9)$ & $1.3(0.9)$ & $5.4(3.2)$ & $3.3(3.3)$ & $5.0(3.5)$ \\
\hline Annual rate & & & $94.9(6.7)$ & $4.9(1.4)$ & $13.4(5.2)$ & $473.7(472.9)$ & $31.6(4.6)$ \\
\hline \multirow[t]{4}{*}{ Basket } & META & 2010 & $73.9(7.8)$ & $0.6(0.3)$ & $0.8(0.6)$ & 0.0 & $25.4(5.2)$ \\
\hline & & 2011 & $147.6(12.2)$ & $2.6(1.0)$ & $18.0(6.3)$ & 0.0 & 36.8 (20.6) \\
\hline & & 2012 & $81.8(8.5)$ & $2.2(1.0)$ & $16.7(12.2)$ & 0.0 & $12.4(4.2)$ \\
\hline & & 2013 & $52.0(6.9)$ & $1.2(1.2)$ & $5.1(3.6)$ & 0.0 & 0.0 \\
\hline Annual rate & & & $87.0(5.5)$ & $1.6(0.5)$ & $9.7(3.5)$ & 0.0 & $18.3(5.1)$ \\
\hline \multirow[t]{4}{*}{ Plot } & GRAN & 2010 & & $2.9(1.6)$ & 12.9 (3.9) & $3.2(1.5)$ & $0.3(0.2)$ \\
\hline & & 2011 & & $2.9(0.2)$ & $20.2(7.6)$ & $4.3(3.4)$ & $25.3(9.2)$ \\
\hline & & 2012 & & $1.3(0.8)$ & $13.1(4.9)$ & $3.5(1.6)$ & $9.6(3.1)$ \\
\hline & & 2013 & & $2.2(1.6)$ & $7.1(2.5)$ & $1.9(1.2)$ & $3.3(1.3)$ \\
\hline Annual rate & & & & $2.3(0.7)$ & $13.3(2.6)$ & $3.2(1.0)$ & $9.6(2.8)$ \\
\hline \multirow[t]{4}{*}{ Plot } & META & 2010 & & $1.4(0.6)$ & $16.1(4.8)$ & $1.0(0.4)$ & $2.4(1.1)$ \\
\hline & & 2011 & & $1.2(0.6)$ & $37.5(10.2)$ & $5.4(1.7)$ & $16.9(4.7)$ \\
\hline & & 2012 & & $0.6(0.2)$ & $13.1(3.9)$ & $1.9(1.0)$ & $8.7(1.8)$ \\
\hline & & 2013 & & $7.2(4.7)$ & $8.7(3.3)$ & $2.2(0.8)$ & $11.7(5.6)$ \\
\hline Annual rate & & & & $2.7(1.3)$ & $18.5(3.4)$ & $2.6(0.6)$ & $9.8(2.0)$ \\
\hline
\end{tabular}


canopy gaps. Jeffrey pine was the dominant tree at both sites, accounting for $84 \%$ of the total canopy cover at GRAN, followed by white fir (12.7\%) and sugar pine (3.3\%). The META site was a monotypic stand of Jeffrey pine. Spatial autocorrelation was significant $(P<0.004)$ but weak for canopy cover $(I=0.05$ at GRAN and 0.09 at META), tree density $(I=0.10$ at GRAN and 0.04 at META), and basal area ( $I=0.06$ at META).

Soil texture of the META site was either loamy sands (26\% of samples) or sandy loams ( $74 \%$ of samples; Table 2). In contrast, most of the soil samples from the GRAN site (see Table 1 in Stephens and Gill 2005 for data summary) were loamy sands $(87 \%)$, followed by sand and sandy loams (both 6\%). Total carbon, coarse fragments (diameters $>2 \mathrm{~mm}$ ), and sodium concentration were significantly lower, and magnesium concentration was significantly higher at META compared to GRAN $(P<0.05)$. Average available phosphorus was only $25 \%$ of GRAN, a highly significant difference $(P<0.01)$.

\section{Fuel deposition}

Overall, annual deposition was highest in 2011 then decreased over the rest of the measurement period. This variation in total annual fuel deposition corresponded with annual precipitation for the study period (Fig. 3). Total precipitation for 2010 to 2011 was the highest among all years, followed by 2009 to 2010, and these were preceded by several years of low precipitation (data not shown). For surface fuels collected in litter baskets, the high fuel load in 2010 was due to large woody (100-hour) fuels from one location in GRAN (Table 3). The only other 100-hour fuel measured was from the same location in 2013. This outlier was removed for the statistical analysis of total fuel loads contingent on forest structure (Figs. 4 and 5), and without this outlier, 2011 clearly had the highest annual fuel loads (Fig. 4). Mean annual deposition rate in the collection baskets for GRAN (6.2 $\mathrm{Mg} \mathrm{ha}^{-1} \mathrm{yr}^{-1}, \mathrm{SD} \pm 4.7 \mathrm{Mg} \mathrm{ha}^{-1} \mathrm{yr}^{-1}$ ) was much higher than META (1.7 $\mathrm{Mg} \mathrm{ha}^{-1} \mathrm{yr}^{-1}, \mathrm{SD} \pm$ $0.8 \mathrm{Mg} \mathrm{ha}^{-1} \mathrm{yr}^{-1}$ ); however, removing the 100-hour fuels from that basket reduced the 2010 mean to $1.5 \mathrm{Mg} \mathrm{ha}^{-1}$ $\left(\mathrm{SD} \pm 0.5 \mathrm{Mg} \mathrm{ha}^{-1}\right)$, and changed the annual rate to 1.5 Mg ha ${ }^{-1} \mathrm{yr}^{-1}\left(\mathrm{SD} \pm 0.6 \mathrm{Mg} \mathrm{ha}^{-1} \mathrm{yr}^{-1}\right)$. The largest contribution of fuels was litter, accounting for 63 to $80 \%$ of the total. Spatial autocorrelations were statistically significant $(P<0.03)$ only at GRAN for litter (Moran's $I=0.06$ ), wood (1- to 100-hour fuels; $I=-0.03$ ), and total fuels $(I=-0.03)$. For the $3 \mathrm{~m}$ plots, average woody fuels deposition rates were higher for META $\left(0.45 \mathrm{Mg} \mathrm{ha}^{-1} \mathrm{yr}^{-1}\right.$, $\mathrm{SD} \pm 0.09 \mathrm{Mg} \mathrm{ha}^{-1} \mathrm{yr}^{-1}$ ) compared to GRAN (0.40 Mg ha $\left.\mathrm{yr}^{-1}, \mathrm{SD} \pm 0.10 \mathrm{Mg} \mathrm{ha}^{-1} \mathrm{yr}^{-1}\right)$. Spatial autocorrelations were similar between sites, with significant $(P<0.05)$ but weak, negative relationships for 1 -hour

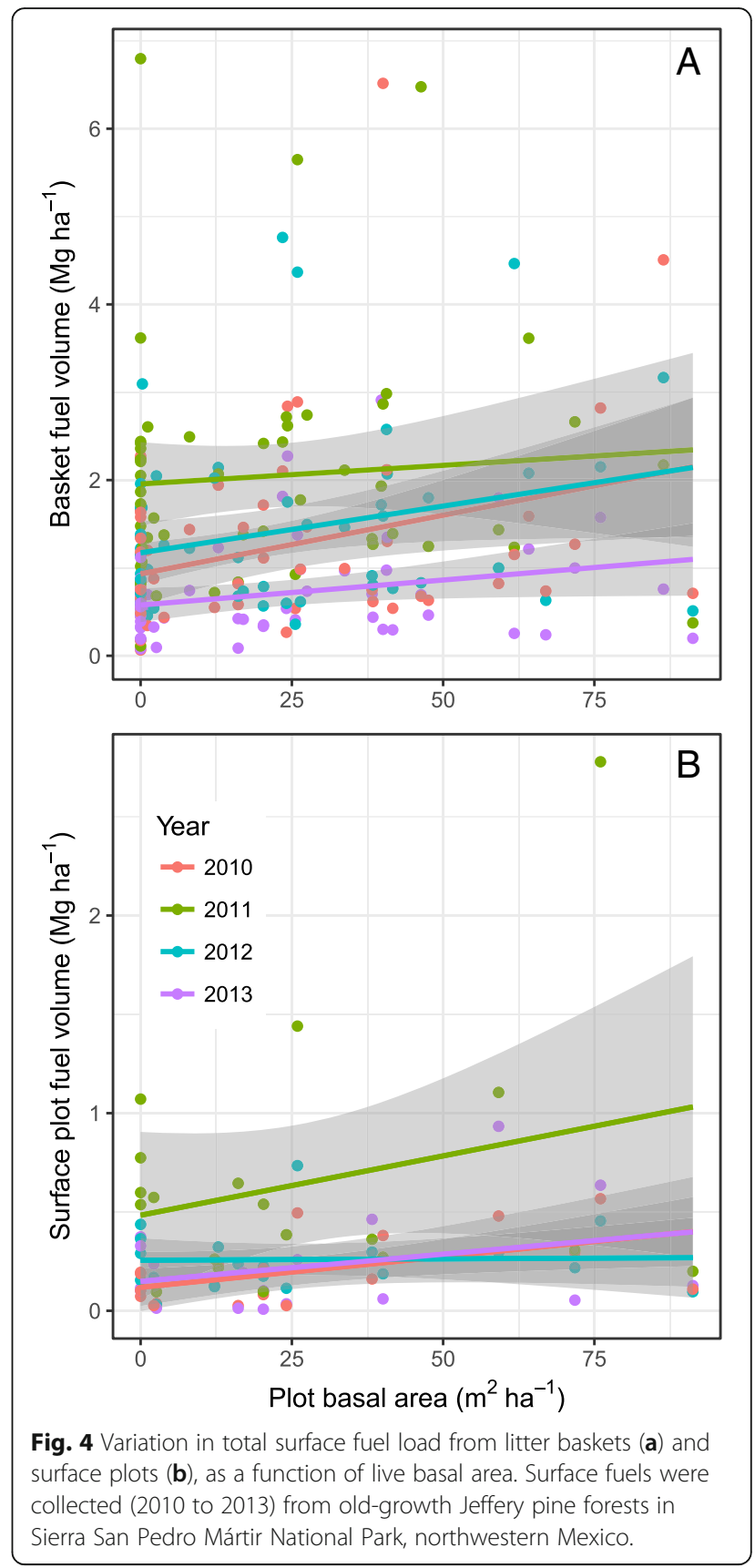

fuels $(I=-0.19$ to -0.16$)$, wood (1-to 100 -hour fuels; $I=-0.15$ to -0.12$)$, and total fuels $(I=-0.16$ to -0.14$)$.

Because of the low spatial autocorrelation in the variables, we did not include a spatial component in the regression models. There was no significant effect of site on any surface fuel variables $(P>0.15)$. When we combined sites, basal area (at the 0.01 ha scale) had a significant positive effect on surface fuel load in both litter baskets (Fig. 3) and on surface plots (Fig. 4b) in some years, but not all years (Fig. 5; see Table 4 for model equations and statistical significance). Effects of canopy 


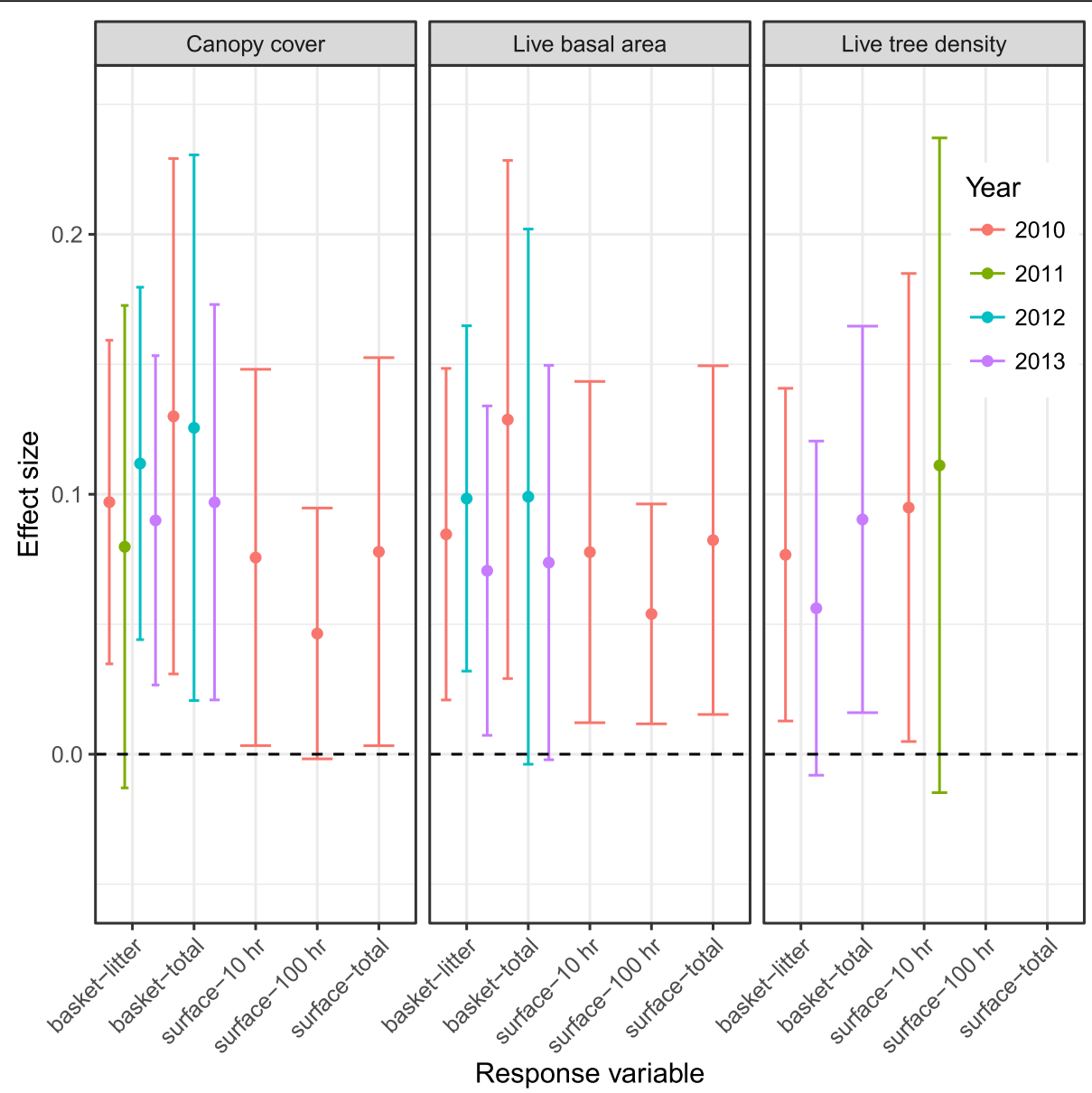

Fig. 5 Effects of canopy, basal area, and density on a suite of surface fuel variables collected (2010 to 2013) from old-growth Jeffery pine forests in Sierra San Pedro Mártir National Park, northwestern Mexico. Effect size is based on standardized variables to facilitate comparison. All variables with marginal significance $(P<0.1)$ are shown; error bars represent two standard deviations around the mean.

cover were similar to basal area, while tree density generally had smaller effects (but still significantly positive in some years; Fig. 5). Forest structure had a greater impact on fuel deposition in litter baskets than on coarse woody debris in surface plots (Fig. 5). The year 2011 was distinctive in that overall fuel deposition rates were higher (Table 3; Fig. 4) but forest structure did not have a significant effect $(P>0.09$; Fig. 5$)$.

\section{Needle decomposition}

For pine needle decay, the mass loss rate ranged from 6.6 to $10.0 \% \mathrm{yr}^{-1}$ at GRAN and 7.1 to $10.8 \% \mathrm{yr}^{-1}$ at META over the 6-year period (Table 5). For the $k$ parameter, GRAN ranged from 0.09 to $0.13($ mean $=0.116$ ) and META ranged from 0.10 to 0.17 (mean $=0.134$ ). There was no significant difference in decay rate $k$ between sites $(t=1.64, \mathrm{df}=16, P=0.12$; Fig. 6). Spatial autocorrelations were similar between sites, with $P$-values for all tests greater than 0.07 . Forest structure had no significant effect on decomposition rates pooled among both sites $(t=0.38,1.16$, and $0.97 ; \mathrm{df}=16$; and $P=0.71$, $0.26,0.34$ for canopy cover, basal area, and density, respectively). Decomposition rates of 0.116 to 0.134 (per year) are on the lower end of published decomposition rates for conifer needle litter in western North America (Fig. 6). For the study period, needle carbon percent stayed the same but nitrogen increased by 35 to $43 \%$.

\section{Discussion}

Quantifying surface fuel dynamics and establishing linkages between overstory forest structure is difficult because canopy and surface fuels vary at different temporal and spatial scales (Agee et al. 1977, Stohlgren 1988, Keifer et al. 2006, Keane 2008, van Mantgem and Schwilk 2009, Fry and Stephens 2010, Keane et al. 2012b, Banwell and Varner 2014, Lydersen et al. 2015). While we identified significant relationships between forest structure and surface fuel loads, unexplained variation overall was high, which is similar to other studies examining relationships at the stand-scale in mixed 
Table 4 Model equations relating fuel loads $\left(\mathrm{Mg} \mathrm{ha}^{-1}\right)$ collected in litter baskets and surface plots to forest structure. SD = standard error of the coefficient, $t=t$-statistic, $P=$ probability, $R^{2}=$ coefficient of determination.

\begin{tabular}{|c|c|c|c|c|c|c|c|}
\hline Response variable & Year & Variable & Coefficient & SD & t & $P$ & $R^{2}$ \\
\hline \multirow{10}{*}{$\begin{array}{l}\text { Basket } \\
\text { (litter) }\end{array}$} & \multirow[t]{3}{*}{2010} & Canopy cover & 0.097 & 0.031 & 3.117 & 0.003 & 0.148 \\
\hline & & Live basal area & 0.085 & 0.032 & 2.655 & 0.010 & 0.112 \\
\hline & & Live tree density & 0.077 & 0.032 & 2.400 & 0.020 & 0.093 \\
\hline & 2011 & Canopy cover & 0.080 & 0.046 & 1.721 & 0.091 & 0.054 \\
\hline & \multirow[t]{3}{*}{2012} & Canopy cover & 0.112 & 0.034 & 3.301 & 0.002 & 0.171 \\
\hline & & Live basal area & 0.098 & 0.033 & 2.963 & 0.005 & 0.142 \\
\hline & & Live tree density & 0.040 & 0.034 & 1.169 & 0.248 & 0.025 \\
\hline & \multirow[t]{3}{*}{2013} & Canopy cover & 0.090 & 0.032 & 2.841 & 0.006 & 0.130 \\
\hline & & Live basal area & 0.071 & 0.032 & 2.229 & 0.030 & 0.084 \\
\hline & & Live tree density & 0.056 & 0.032 & 1.749 & 0.086 & 0.054 \\
\hline \multirow{9}{*}{$\begin{array}{l}\text { Basket } \\
\text { (total) }\end{array}$} & \multirow[t]{3}{*}{2010} & Canopy cover & 0.130 & 0.050 & 2.623 & 0.011 & 0.109 \\
\hline & & Live basal area & 0.129 & 0.050 & 2.584 & 0.012 & 0.107 \\
\hline & & Live tree density & 0.067 & 0.052 & 1.295 & 0.201 & 0.029 \\
\hline & \multirow[t]{3}{*}{2012} & Canopy cover & 0.126 & 0.053 & 2.393 & 0.020 & 0.098 \\
\hline & & Live basal area & 0.099 & 0.052 & 1.925 & 0.060 & 0.065 \\
\hline & & Live tree density & 0.014 & 0.052 & 0.272 & 0.787 & 0.001 \\
\hline & \multirow[t]{3}{*}{2013} & Canopy cover & 0.097 & 0.038 & 2.550 & 0.014 & 0.107 \\
\hline & & Live basal area & 0.074 & 0.038 & 1.944 & 0.057 & 0.065 \\
\hline & & Live tree density & 0.090 & 0.037 & 2.430 & 0.018 & 0.099 \\
\hline \multirow{10}{*}{$\begin{array}{l}\text { Surface plot } \\
\text { (10-hour) }\end{array}$} & \multirow[t]{3}{*}{2010} & Canopy cover & 0.076 & 0.036 & 2.092 & 0.051 & 0.196 \\
\hline & & Live basal area & 0.078 & 0.033 & 2.370 & 0.029 & 0.238 \\
\hline & & Live tree density & 0.095 & 0.045 & 2.109 & 0.049 & 0.198 \\
\hline & 2011 & Live tree density & 0.111 & 0.063 & 1.765 & 0.095 & 0.155 \\
\hline & \multirow[t]{3}{*}{2012} & Canopy cover & 0.032 & 0.039 & 0.821 & 0.423 & 0.038 \\
\hline & & Live basal area & 0.034 & 0.036 & 0.958 & 0.351 & 0.051 \\
\hline & & Live tree density & 0.052 & 0.048 & 1.077 & 0.297 & 0.064 \\
\hline & \multirow[t]{3}{*}{2013} & Canopy cover & -0.022 & 0.039 & -0.571 & 0.575 & 0.018 \\
\hline & & Live basal area & 0.008 & 0.036 & 0.216 & 0.831 & 0.003 \\
\hline & & Live tree density & -0.014 & 0.048 & -0.294 & 0.772 & 0.005 \\
\hline \multirow{9}{*}{$\begin{array}{l}\text { Surface plot } \\
\text { (100-hour) }\end{array}$} & \multirow[t]{3}{*}{2010} & Canopy cover & 0.047 & 0.024 & 1.926 & 0.070 & 0.171 \\
\hline & & Live basal area & 0.054 & 0.021 & 2.553 & 0.020 & 0.266 \\
\hline & & Live tree density & 0.011 & 0.033 & 0.346 & 0.733 & 0.007 \\
\hline & \multirow[t]{3}{*}{2012} & Canopy cover & -0.023 & 0.029 & -0.801 & 0.434 & 0.036 \\
\hline & & Live basal area & -0.008 & 0.028 & -0.298 & 0.769 & 0.005 \\
\hline & & Live tree density & -0.045 & 0.036 & -1.259 & 0.225 & 0.085 \\
\hline & \multirow[t]{3}{*}{2013} & Canopy cover & -0.010 & 0.025 & -0.397 & 0.696 & 0.009 \\
\hline & & Live basal area & -0.006 & 0.023 & -0.260 & 0.798 & 0.004 \\
\hline & & Live tree density & 0.023 & 0.030 & 0.754 & 0.461 & 0.031 \\
\hline \multirow{5}{*}{$\begin{array}{l}\text { Surface plot } \\
\text { (total) }\end{array}$} & \multirow[t]{3}{*}{2010} & Canopy cover & 0.078 & 0.037 & 2.088 & 0.051 & 0.195 \\
\hline & & Live basal area & 0.082 & 0.034 & 2.456 & 0.024 & 0.251 \\
\hline & & Live tree density & 0.079 & 0.048 & 1.642 & 0.118 & 0.130 \\
\hline & \multirow[t]{2}{*}{2012} & Canopy cover & 0.001 & 0.035 & 0.034 & 0.974 & 0.000 \\
\hline & & Live basal area & 0.005 & 0.033 & 0.147 & 0.885 & 0.001 \\
\hline
\end{tabular}


Table 4 Model equations relating fuel loads $\left(\mathrm{Mg} \mathrm{ha}^{-1}\right)$ collected in litter baskets and surface plots to forest structure. SD = standard error of the coefficient, $t=t$-statistic, $P=$ probability, $R^{2}=$ coefficient of determination. (Continued)

\begin{tabular}{|c|c|c|c|c|c|c|c|}
\hline Response variable & Year & Variable & Coefficient & SD & $t$ & $P$ & $\mathrm{R}^{2}$ \\
\hline & & Live tree density & 0.007 & 0.044 & 0.155 & 0.879 & 0.001 \\
\hline & 2013 & Canopy cover & 0.035 & 0.052 & 0.676 & 0.508 & 0.025 \\
\hline & & Live basal area & 0.055 & 0.048 & 1.141 & 0.269 & 0.067 \\
\hline & & Live tree density & 0.043 & 0.065 & 0.665 & 0.515 & 0.024 \\
\hline
\end{tabular}

conifer forests (Lydersen et al. 2015). Recent results highlight the need to describe patterns at the tree scale and plot scale (van Wagtendonk and Moore 2010, Keane et al. 2012a), rather than generalizing across stands, as is commonly done for forest management.

SSPM fuel deposition rates were within the wide ranges reported for litter $\left(0.029\right.$ to $\left.0.36 \mathrm{~kg} \mathrm{~m}^{-1} \mathrm{yr}^{-1}\right)$ and woody fuels $\left(0.01\right.$ to $0.45 \mathrm{~kg} \mathrm{~m}^{-1} \mathrm{yr}^{-1}$ ) from other conifer forests in the western US (see Table 1 in Keane 2008; van Wagtendonk and Moore 2010). In comparison to old-growth Jeffrey pine plots from Yosemite National Park (van Wagtendonk and Moore 2010), our mean annual deposition rates were 15 to $36 \%$ below the rates reported for litter and fragments (bark flakes, cone scales, etc.), and 13 to $58 \%$ below rates for woody fuels. The expectation was that, since our study area is a xeric, low productivity forest, supporting very low herbaceous fuels, our values would be at the low end of the range; fire exclusion in Yosemite for approximately 100 years (circa 1875 to 1975 ) could have increased stand density and fuel loads in some areas where van Wagtendonk and Moore (2010) did their work.

There was temporal and spatial variation in fuel deposition, suggesting that winter storm activity during the course of the study may have been an important source of localized surface fuel loads (Keane 2013, Stalling et al. 2017). Deposition of 100-hour fuels at one litter basket resulted in a 10-fold higher total fuel load in 2010. The total precipitation from 2009 to 2010 and 2010 to 2011 was approximately 36 to $67 \%$ higher than the several years prior, and this may have contributed to high deposition rates of litter in 2011, which was the main contributor to total fuel loading (Table 3). High winds and rainfall and snowfall amounts may cause tree mortality and damage to canopies of trees, transferring aerial fuels to surface fuels (Brown and See 1981, Grier 1988) in relatively shorts periods, contributing to the spatially clumped distribution of coarse fuel loads (Lundquist 2007, Fry and Stephens 2010, Lydersen et al. 2015). A limited sample size and low snag densities (Stephens and Gill 2005) in this study area prohibited an examination of relationships with coarse fuels (1000-hour).

We found that forest structure characteristics such as canopy cover, live basal area, and tree density were associated with fuel loads but the influence varied by year and fuel type, with litter deposition generally being the most closely tied to forest structure (Fig. 5). Similar to our study, both Keane (2008) and Lydersen et al. (2015) found that total or individual species basal area had high importance factors when predicting fuel loads. Both studies suggested that the stronger relationships with basal area were due to the influence of both aboveground biomass and large trees on surface fuel inputs. Basal area had only a moderate influence on fuel load in this study, with the strongest influence in 2010 for woody fuels collected in the surface plots. Canopy cover, while only moderate in its overall effect size, was important across fuel types, specifically 100-hour fuels. This is similar to Lydersen et al. (2015) for which species-specific basal area and total canopy cover were the strongest predictors of surface fuel loads.

Table 5 Composition of Jeffrey pine needles following one, two, and six years of decay from initial collection (2009). Values represent mean with one standard error of the mean in parentheses. GRAN = granitic site, META = metamorphic site, $N=$ nitrogen, $P=$ phosphorus, $K=$ potassium.

\begin{tabular}{|c|c|c|c|c|c|c|}
\hline Site & Year & Weight (g) & Carbon (\%) & N (\%) & P (\%) & K (\%) \\
\hline \multirow[t]{4}{*}{ GRAN } & 2009 & $37.2(0.1)$ & $49.7(0.1)$ & $1.11(0.01)$ & $0.11(0.0)$ & $0.52(0.03)$ \\
\hline & 2010 & $31.7(0.4)$ & $54.2(0.1)$ & $1.38(0.02)$ & $0.10(0.0)$ & $0.29(0.03)$ \\
\hline & 2011 & $29.4(0.7)$ & $52.1(0.9)$ & $1.44(0.05)$ & $0.10(0.0)$ & $0.23(0.03)$ \\
\hline & 2015 & $19.0(0.9)$ & $53.0(0.4)$ & $1.97(0.08)$ & $0.09(0.0)$ & $0.09(0.02)$ \\
\hline \multirow[t]{4}{*}{ META } & 2009 & $37.4(0.6)$ & $49.2(0.1)$ & $1.13(0.02)$ & $0.14(0.01)$ & $0.55(0.01)$ \\
\hline & 2010 & $30.4(0.2)$ & $54.5(0.1)$ & $1.28(0.02)$ & $0.11(0.00)$ & $0.18(0.03)$ \\
\hline & 2011 & $28.1(0.3)$ & $52.6(0.3)$ & $1.33(0.04)$ & $0.10(0.01)$ & $0.17(0.02)$ \\
\hline & 2015 & $18.6(1.3)$ & $53.2(0.5)$ & $1.74(0.05)$ & $0.09(0.01)$ & $0.09(0.02)$ \\
\hline
\end{tabular}




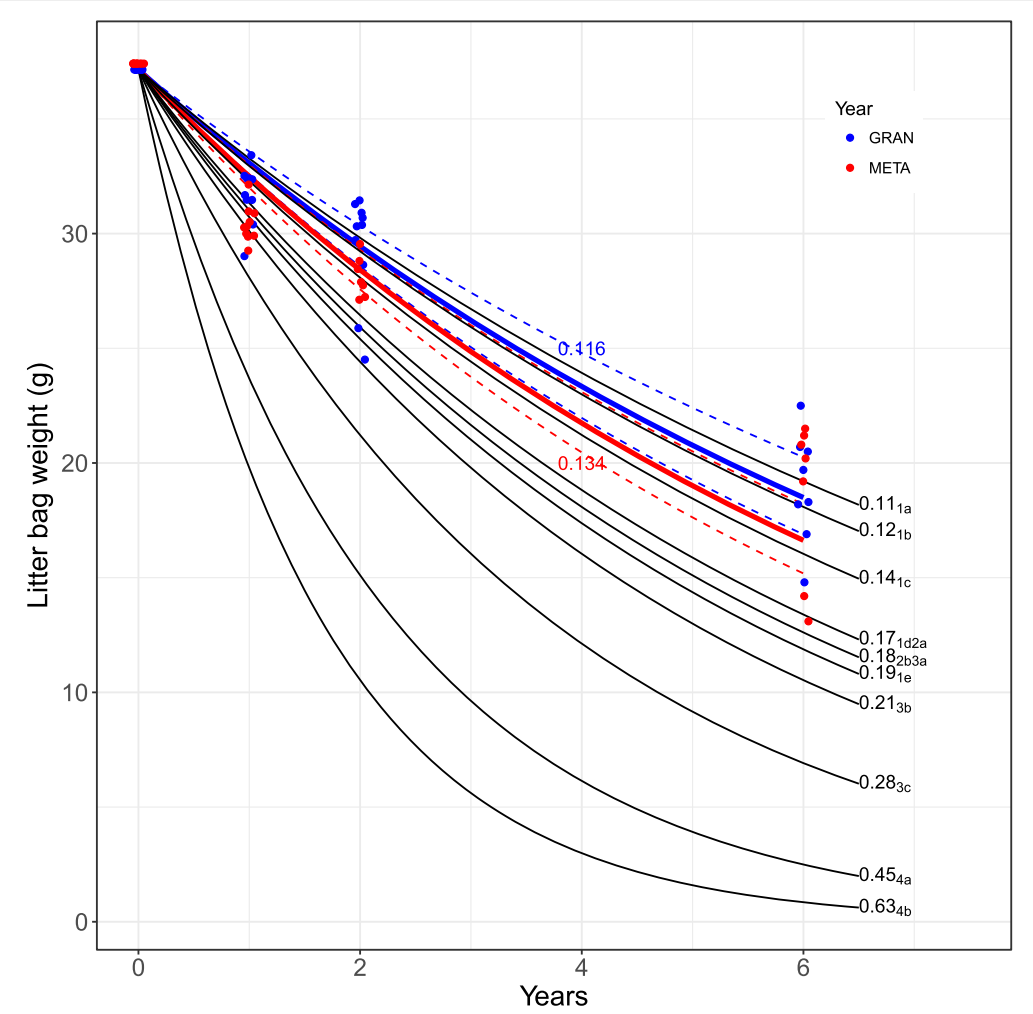

Fig. 6 Change in Jeffrey pine needle weight, expressed using the exponential decay function fit to each plot over six years. Colored lines represent mean decay $(k$ ) parameter values for the granitic (blue) and metamorphic (red) sites, with dashed lines representing $95 \%$ confidence intervals. Solid black lines represent other published $k$ values for litter in Western conifer species: (1) from Keane (2008) for Pinus ponderosa (1a), Pseudotsuga menziesii (1b), Abies amabilis (Douglas) James Forbes (1c) and Thuja plicata Donn ex D. Don (1d) in their respective forest types in western Montana, USA; (2) from Taylor et al. (1991) for Pinus contorta (2a) and Picea engelmanii Parry ex Engelm. (2b) in P. engelmanii forest in Alberta, Canada; (3) from Stohlgren (1988) for Pinus lambertiana Douglas (3a), Abies concolor (3b), and Calocedrus decurrens (Torr.) Florin (3c) in mixed-conifer forest of the Sierra Nevada; and (4) from Edmonds (1980) for Abies amabilis (4a) and Pseudotsuga menziesii (4b) in their respective forest types in western Washington, USA.

Despite the close proximity of the two study sites that experienced a similar fire regime (Stephens et al. 2003), the sites' edaphic properties are distinct and likely the main contributor to differences in stand structure (Fry et al. 2014). In addition to soil texture, differences in several other soil properties included coarse fragments, carbon (\%), and phosphorus $\left(\mathrm{Mg} \mathrm{kg}^{-1}\right)$. Combined with nitrogen, these three main soil components regulate tree growth. Finer soil texture, as it relates to water filtration (more loam than sand), is generally indicative of better growing conditions. Nitrogen concentration was similar at both sites, although phosphorus concentrations were four times higher at GRAN. These factors, combined, resulted in fewer but larger trees at GRAN compared to META (Fry et al. 2014).

Both GRAN and META had among the lowest reported needle decay rates for conifer forests compared to forests in the western US (see Table 1 in Keane 2008). While percent phosphorous and potassium showed similar patterns of decay to that of needle mass, carbon remained static and nitrogen appeared to increase over the six years. The long residence times for the latter elements are a result of translocation and immobilization of decomposers (Gosz et al. 1976). Similar to Keane (2008), we did not find a correlation between forest structure and decay rates. $\mathrm{Nu}$ merous factors influence decay rates such as tree spatial patterns, soil type, and microclimate (reviewed in Gartner and Cardon 2004), and likely operate at much finer spatial scales than what was measured in this study.

At the stand scale, forest surface fuels at the SSPM have high inherent variability (Stephens 2004; Stephens et al. 2007, 2008; Fry and Stephens 2010), and this is a characteristic identified in similar old-growth, fire-frequent conifer forests in western North America (e.g., Keane 2013, Banwell and Varner 2014, Collins et al. 2016). One useful application of this result may be in the design of more heterogeneous fuel and forest restoration treatments. Forest managers are increasingly emphasizing restoration of resilient forest conditions that also provide habitat for multiple species of concern (North et al. 2009b; Stephens et al. 2010, 2016). Management actions that increase overstory heterogeneity may also lead to greater diversity in surface fuels, and this would influence subsequent fire 
behavior and effects of either prescribed or managed wildfire. For example, stands that have clustered associations of tree species or tree groupings (Larson and Churchill 2012, Lydersen et al. 2013, Fry et al. 2014) as opposed to being distributed more uniformly may produce greater diversity in fuel bed characteristics in the future, and would therefore be expected to experience a greater variety of fire effects (Lydersen et al. 2015). Perhaps future fire modeling efforts will incorporate this type of variability in surface fuels into the necessary fuel characterizations.

\section{Conclusion}

Our findings illustrate the wide range in variation in surface fuel dynamics (deposition and decomposition) that is characteristic of mixed conifer-Jeffery pine forests in the SSPM (Stephens 2004, Stephens and Gill 2005, Fry and Stephens 2010, Fry et al. 2014). Significant spatial correlations were identified for litter, woody fuels, and total fuels; overall, the relationships were weak and some correlations were negative. Ideally, a finer-scale sampling scheme $(<10$ to $20 \mathrm{~m})$, across a larger study area ( $>4 \mathrm{ha})$, would capture more variation in forest structure and fuels (Dunbar-Irwin and Safford 2016), especially the high deposition events that were considered outliers in this study (see also Fry and Stephens 2010).

Our results show that the relationship between overstory forest structure and fuels deposition is complex despite sampling a fairly homogeneous forest (i.e., same substrate, forest type, and fire history). Obvious forest structure variables such as canopy cover and live tree basal area explained some of the variation in fuels deposition, but only in some years. Other variables such as species morphology, stand development, and other disturbances play an important role in explaining spatiotemporal patterns (Keane 2008, Keane et al. 2012b).

Historically, our study sites burned frequently, with a median fire return interval ranging from 5 to 13 years (Stephens et al. 2003). The spatially heterogenous, patchy nature of fuels and forest structure described here and in previous studies is, in part, a consequence of an intact fire regime consisting of frequent, predominately low- to moderate-intensity fires. However, the current fire-free interval of $40+$ years is unusual in the multi-century fire-scar record (Stephens et al. 2003, Skinner et al. 2008), and this is due to a policy of fire exclusion throughout the SSPM. Surface fuels in some conifer forests of the SSPM are higher than expected due to this policy and the efficiency at which the fire suppression crews are extinguishing all fires (Dunbar-Irwin and Safford 2016). Policies could be modified to incorporate both managed wildfire and prescribed fire to avoid forest management issues associated with over a century of fire suppression, similar to that of forests in the western US (Stephens et al. 2008, Dunbar-Irwin and Safford 2016, Rivera-Huerta et al. 2015).

\section{Acknowledgements}

This study was supported by the USDA Agricultural Experiment Station funds from the University of California, Berkeley, and SEMERNAT (Mexican Ministry of the Environment) permits NUM/SGPA/DGVS/ 3315, NUM/SGPA/DGVS/04036 and NUM/SGPAVDGVS/04075. We thank E. Franco, H. Safford, R. Vargas, M. Gross, C. Stephens, K. Stephens, and all the volunteers who assisted in collecting field data over the years. We especially thank E. Moghaddas for her help in soil sample collection, and J. Bertenshaw for analyzing the soils in the lab.

\section{Funding}

This study was supported by the USDA Agricultural Experiment Station funds from the University of California.

\section{Availability of data and materials}

The datasets used or analyzed during the current study are available from the corresponding author on reasonable request.

\section{Authors' contributions}

DLF, BMC, and SLS designed the study and collected data. DLF, ATP, and JTS analyzed data and interpreted results. DLF, JTS, SLS, BMC, and ATP contributed to the writing of the manuscript. All authors read and approved the final manuscript.

Ethics approval and consent to participate

Not applicable.

\section{Consent for publication}

Not applicable.

\section{Competing interests}

The authors declare that they have no competing interests.

\section{Publisher's Note}

Springer Nature remains neutral with regard to jurisdictional claims in published maps and institutional affiliations.

\section{Author details \\ ${ }^{1}$ Department of Environmental Science, Policy, and Management, University of California, 137 Mulford Hall, Berkeley, California 94720-3114, USA. ${ }^{2}$ Center for Fire Research and Outreach, University of California, 137 Mulford Hall, Berkeley, California 94720-3114, USA.}

Received: 9 October 2018 Accepted: 10 October 2018 Published online: 19 December 2018

\section{References}

Agee, J.K., R.H. Wakimoto, and H.H. Biswell. 1977. Fire and fuel dynamics of Sierra Nevada conifers. Forest Ecology and Management 1: 255-265 https://doi.org/ 10.1016/0378-1127(76)90030-X.

Arroyo, L.A., C. Pascual, and J.A. Manzanera. 2008. Fire models and methods to map fuel types: the role of remote sensing. Forest Ecology and Management 256: 1239-1252 https://doi.org/10.1016/j.foreco.2008.06.048.

Banwell, E.M., and J.M. Varner. 2014. Structure and composition of forest floor fuels in long-unburned Jeffrey pine-white fir forests of the Lake Tahoe Basin, USA. International Journal of Wildland Fire 23: 363-372 https://doi.org/10. 1071/WF13025.

Barbour, M., E. Kelley, P. Maloney, D. Rizzo, E. Royce, and J. Fites-Kaufmann. 2002. Present and past old-growth forests of the Lake Tahoe Basin, Sierra Nevada, US. Journal of Vegetation Science 13: 461-472 https://doi.org/10.1111/j.16541103.2002.tb02073.x.

Bechtold, W.A. 2004. Largest-crown-width prediction models for 53 species in the western United States. Western Journal of Applied Forestry 19: 245-251.

Boyden, S., D. Binkley, and W. Shepperd. 2005. Spatial and temporal patterns in structure, regeneration, and mortality of an old-growth ponderosa pine forest in the Colorado Front Range. Forest Ecology and Management 219: 4355 https://doi.org/10.1016/j.foreco.2005.08.041.

Brown, J.K. 1974. Handbook for inventorying downed woody material. USDA Forest Service General Technical Report INT-16. Ogden: Intermountain Forest and Range Experiment Station.

Brown, J.K., and C.D. Bevins. 1986. Surface fuel loadings and predicted fire behavior for vegetation types in the northern Rocky Mountains. USDA Forest Service 
General Technical Report INT-358. Ogden: Intermountain Forest and Range Experiment Station.

Brown, J.K., and T.E. See. 1981. Downed dead woody fuel and biomass in the northern Rocky Mountains. USDA Forest Service General Technical Report INT117. Ogden: Intermountain Forest and Range Experiment Station.

Collins, B.M., J.M. Lydersen, D.L. Fry, K. Wilkin, T. Moody, and S.L. Stephens. 2016 Variability in vegetation and surface fuels across mixed-conifer-dominated landscapes with over 40 years of natural fire. Forest Ecology and Management 381: 74-83 https://doi.org/10.1016/j.foreco.2016.09.010.

Development Core Team, R. 2014. R: a language and environment for statistical computing. Vienna: R Foundation for Statistical Computing

Dunbar-Irwin, M., and H.D. Safford. 2016. Climatic and structural comparison of yellow pine and mixed-conifer forests in northern Baja California (México) and the eastern Sierra Nevada (California, USA). Forest Ecology and Management 363: 252-266 https://doi.org/10.1016/j.foreco.2015.12.039.

Edmonds, R.L. 1980. Litter decomposition and nutrient release in Douglas-fir, red alder, western hemlock, and Pacific silver fir ecosystems in western Washington. Canadian Journal of Forest Research 10: 327-337 https:/doi.org/ 10.1139/x80-056

Fonda, R.W., and J.M. Varner. 2004. Burning characteristics of cones from eight pine species. Northwest Science 78: 322-333.

Fry, D.L., and S.L. Stephens. 2010. Stand-level spatial dependence in an old-growth Jeffrey pine-mixed conifer forest, Sierra San Pedro Martir, Mexico. Canadian Journal of Forest Research 40: 1814-1830 https://doi.org/10.1139/X10-122.

Fry, D.L., S.L. Stephens, B.M. Collins, M.P. North, E. Franco-Vizcaino, and S.J. Gill. 2014. Contrasting spatial patterns in active-fire and fire-suppressed mediterranean climate old-growth mixed conifer forests. PLOS ONE 9 (2): e88985 https://doi.org/10.1371/journal.pone.0088985.

Gartner, T.B., and Z.G. Cardon. 2004. Decomposition dynamics in mixed-species leaf litter. Oikos 104: 230-246 https://doi.org/10.1111/j.0030-1299.2004.12738.x.

Gee, G.W., and J.W. Bauder. 1986. Particle-size analysis. In Methods of soil analysis, part 1. Physical and mineralogical methods. Agronomy Monograph No. 9, ed. A. Klute, 2nd ed., 383-411. Madison: American Society of Agronomy/Soil Science Society of America.

Gosz, J.R., G.E. Likens, and F.H. Bormann. 1976. Organic matter and nutrient dynamics of the forest and forest floor in the Hubbard Brook Forest. Oecologia 22: 305-320 https://doi.org/10.1007/BF00345310.

Grier, C.C. 1988. Foliage loss due to snow, wind, and winter drying damage: its effects on leaf biomass of some Western conifer forests. Canadian Journal of Forest Research 18: 1097-1102 https://doi.org/10.1139/x88-168.

Kalra, Y.P., and D.G. Maynard. 1991. Methods manual for forest soil and plant analysis. Forestry Canada Information Report NOR-X319. Edmonton: Northwest Region, Northern Forestry Centre.

Keane, R.E. 2008. Biophysical controls on surface fuel litterfall and decomposition in the northern Rocky Mountains, USA. Canadian Journal of Forest Research 38: 1431-1445 https://doi.org/10.1139/X08-003.

Keane, R.E. 2013. Describing wildland surface fuel loading for fire management: a review of approaches, methods and systems. International Journal of Wildland Fire 22: 51-62 https://doi.org/10.1071/WF11139.

Keane, R.E., K. Gray, and K. Bacciu. 2012b. Spatial variability of wildland fuel characteristics in northern Rocky Mountain ecosystems. USDA Forest Service Research Paper RMRS-98. Fort Collins: Rocky Mountain Research Station.

Keane, R.E., K. Gray, V. Bacciu, and S. Leirfallom. 2012a. Spatial scaling of wildland fuels for six forest and rangeland ecosystems of the northern Rocky Mountains, USA. Landscape Ecology 27: 1213-1234 https://doi.org/10.1007/ s10980-012-9773-9

Keane, R.E., P. Morgan, and S.W. Running. 1996. FIRE-BGC — a mechanistic ecological process model for simulating fire succession on coniferous forest landscapes of the northern Rocky Mountains. USDA Forest Service Research Paper RMRS-484. Ogden: Intermountain Research Station.

Keifer, M., J.W. van Wagtendonk, and M. Buhler. 2006. Long-term surface fuel accumulation in burned and unburned mixed-conifer forests of the central and southern Sierra Nevada, CA USA. Fire Ecology 2 (1): 53-72 https://doi.org/ 10.4996/fireecology.0201053.

Larson, A.J., and D. Churchill. 2012. Tree spatial patterns in fire-frequent forests of western North America, including mechanisms of pattern formation and implications for designing fuel reduction and restoration treatments. Forest Ecology and Management 267: 74-92 https://doi.org/10.1016/j.foreco.2011.11.038.

Lundquist, J.E. 2007. The relative influence of diseases and other small-scale disturbances on fuel loading in the Black Hills. Plant Disease 91: 147-152 https://doi.org/10.1094/PDIS-91-2-0147.
Lydersen, J.M., B.M. Collins, E.E. Knapp, G.B. Roller, F. Zhao, and S.L. Stephens. 2015. Relating fuel loads to overstory structure and composition in a Sierra Nevada mixed-conifer forest. International Journal of Wildland Fire 24: 484494 https://doi.org/10.1071/WF13066.

Lydersen, J.M., E.E. Knapp, M.P. North, and B.M. Collins. 2013. Quantifying spatial patterns of tree groups and gaps in mixed-conifer forests: reference conditions and long-term changes following fire suppression and logging. Forest Ecology and Management 304: 370-382 https://doi.org/10.1016/j. foreco.2013.05.023.

Minnich, R.A., M.G. Barbour, J.H. Burk, and R.F. Fernau. 1995. Sixty years of change in California conifer forests of the San Bernardino Mountains. Conservation Biology 9: 902-914 https://doi.org/10.1046/j.1523-1739.1995.09040902.x.

Minnich, R.A., M.G. Barbour, J.H. Burk, and J. Sosa-Ramírez. 2000. Californian mixed-conifer forests under unmanaged fire regimes in the Sierra San Pedro Mártir, Baja California, Mexico. Journal of Biogeography 27: 105-129 https:// doi.org/10.1046/j.1365-2699.2000.00368.x.

Minnich, R.A., and E. Franco. 1998. Land of chamise and pines: historical accounts and current status of northern Baja California's vegetation. University of California publications in botany. Vol. 80. Berkeley: University of California Press.

Moran, P.A.P. 1950. Notes on continuous stochastic phenomena. Biometrika 37: 17-23 https://doi.org/10.1093/biomet/37.1-2.17.

North, M., P. Stine, K. O'Hara, W. Zielinski, and S.L. Stephens. 2009b. An ecosystems management strategy for sierra mixed-conifer forests. USDA Forest Service General Technical Report PSW-220. Albany: Pacific Southwest Research Station.

North, M., K. Van de Water, S.L. Stephens, and B.M. Collins. 2009a. Climate, rain shadow, and human-use influences on eastern Sierra Nevada fire regimes. Fire Ecology 5: 20-34 https://doi.org/10.4996/fireecology.0503020.

Ottmar, R.D., J.I. Blake, and W.T. Crolly. 2012. Using fine-scale fuel measurements to assess wildland fuels, potential fire behavior and hazard mitigation treatments in the southeastern USA. Forest Ecology and Management 273: 13 https://doi.org/10.1016/j.foreco.2011.11.003.

Potter, D.A. 1998. Forested communities of the upper montane in the central and southern Sierra Nevada. USDA Forest Service General Technical Report PSW-169. Albany: Pacific Southwest Research Station.

Rivera-Huerta, H., H.D. Safford, and J.D. Miller. 2015. Patterns and trends in burned area and fire severity from 1984 to 2010 in the Sierra de San Pedro Mártir, Baja California, Mexico. Fire Ecology 12: 52-72 https://doi.org/10.4996/ fireecology.1201052.

Safford, H.D., and J.T. Stevens. 2017. Natural Range of Variation (NRV) for yellow pine and mixed conifer forests in the Sierra Nevada, southern Cascades, and Modoc and Inyo national forests, California, USA. USDA Forest Service General Technical Report, PSW-GTR-256. Albany: Pacific Southwest Research Station.

Skinner, C.N., J.H. Burk, M.G. Barbour, E. Franco-Vizcaíno, and S.L. Stephens. 2008. Influences of climate on fire regimes in montane forests of north-western Mexico. Journal of Biogeography 35: 1436-1451 https://doi.org/10.1111/j.13652699.2008.01893.x.

Stalling, C., R.E. Keane, and M. Retzlaff. 2017. Surface fuel changes after severe disturbances in northern Rocky Mountain ecosystems. Forest Ecology and Management 400: 28-47 https://doi.org/10.1111/j.1365-2699.2008.01893.x.

Stephens, S.L. 1998. Evaluation of the effects of silvicultural and fuels treatments on potential fire behaviour in Sierra Nevada mixed-conifer forests. Forest Ecology and Management 105: 21-34 https://doi.org/10.1111/j.1365-2699. 2008.01893.x

Stephens, S.L. 2001. Fire history of adjacent Jeffrey pine and upper montane forests in the eastern Sierra Nevada. International Journal of Wildland Fire 10: 161-167 https://doi.org/10.1111/j.1365-2699.2008.01893.x.

Stephens, S.L. 2004. Fuel loads, snag abundance, and snag recruitment in an unmanaged Jeffrey pine-mixed conifer forest in northwestern Mexico. Forest Ecology and Management 199: 103-113 https:/doi.org/10.1111/j.1365-2699.2008.01893.x.

Stephens, S.L., B.M. Collins, E. Biber, and P.Z. Fulé. 2016. US federal fire and forest policy: emphasizing resilience in dry forests. Ecosphere 7 (11): e01584 https:// doi.org/10.1002/ecs2.1584.

Stephens, S.L., and D.L. Fry. 2005. Spatial distribution of regeneration patches in an old-growth Jeffrey pine-mixed conifer forest in northwestern Mexico. Journal of Vegetation Science 16: 693-702.

Stephens, S.L., D.L. Fry, and E. Franco-Vizcaíno. 2008. Wildfire and spatial patterns in forests in northwestern Mexico: the United States wishes it had similar problems. Ecol Soc 13 (2): 10 https://doi.org/10.5751/ES-02380-130210.

Stephens, S.L., D.L. Fry, E. Franco-Vizcaíno, B.M. Collins, and J.J. Moghaddas. 2007. Coarse woody debris and canopy cover in an old-growth Jeffery pine-mixed 
conifer forest from the Sierra San Pedro Mártir, Mexico. Forest Ecology and Management 240: 87-95 https://doi.org/10.1016/j.foreco.2006.12.012.

Stephens, S.L., and S.J. Gill. 2005. Forest structure and mortality in an old-growth Jeffrey pine-mixed conifer forest in northwestern Mexico. Forest Ecology and Management 205: 15-28 https://doi.org/10.1111/j.1365-2699.2008.01893.x.

Stephens, S.L., C.I. Millar, and B.M. Collins. 2010. Operational approaches to managing forests of the future in Mediterranean regions within a context of changing climates. Environmental Research Letters 5: 024003 https://doi.org/ 10.1088/1748-9326/5/2/024003.

Stephens, S.L., C.N. Skinner, and S.J. Gill. 2003. Dendrochronology-based fire history of Jeffrey pine-mixed conifer forests in the Sierra San Pedro Mártir, Mexico. Canadian Journal of Forest Research 33: 1090-1101 https://doi.org/10. 1111/j.1365-2699.2008.01893.x.

Stohlgren, T.J. 1988. Litter dynamics in two Sierran mixed conifer forests. I. Litterfall and decomposition rates. Canadian Journal of Forest Research 18: 1127-1135 https://doi.org/10.1139/×88-174.

Sumner, M.E., and W.P. Miller. 1996. Cation exchange capacity and exchange coefficients. In Methods of soil analysis, part 3: chemical methods, SSSA book series 5, ed. D.L. Sparks, 1201-1229. Madison: Soil Science Society of America.

Taylor, A.H. 2004. Identifying forest reference conditions on early cut-over lands, Lake Tahoe Basin, USA. Ecological Applications 14: 1903-1920 https://doi.org/ 10.1890/02-5257.

Taylor, B.R., C.E. Prescott, W.J.F. Parsons, and D. Parkinson. 1991. Substrate control of litter decomposition in four Rocky Mountain coniferous forests. Canadian Journal of Botany 69: 2242-2250 https://doi.org/10.1139/b91-281.

van Mantgem, P.J., and D.W. Schwilk. 2009. Negligible influence of spatial autocorrelation in the assessment of fire effects in a mixed conifer forest. Fire Ecology 5: 116-125 https://doi.org/10.4996/fireecology.0502116.

van Wagtendonk, J.W. 1985. Fire suppression effects on fuels and succession in short fire interval wilderness ecosystems. In Proceedings-symposium and workshop on wilderness fire. USDA Forest Service General Technical Report INT82, ed. J. Lotan, B. Kilgore, W. Fischer, and R. Mutch, 119-126. Ogden: Intermountain Forest and Range Experiment Station.

van Wagtendonk, J.W., J.M. Benedict, and W.M. Sydoriak. 1996. Physical properties of woody fuel particles of Sierra Nevada conifers. International Journal of Wildland Fire 6: 117-123 https://doi.org/10.1071/WF9960117.

van Wagtendonk, J.W., J.M. Benedict, and W.M. Sydoriak. 1998a. Fuel bed characteristics of Sierra Nevada conifers. Western Journal of Applied Forestry 13: 73-84.

van Wagtendonk, J.W., J. Fites-Kaufman, H.D. Safford, M.P. North, and B.M. Collins. 2018. Sierra Nevada Bioregion. In Fire in California ecosystems, ed. J.W. van Wagtendonk, N. Sugihara, S.L. Stephens, K. Shaffer, J. Fites-Kaufman, and A. Thode, 2nd ed., 264-294. Berkeley: University of California Press.

van Wagtendonk, J.W., and P.E. Moore. 2010. Fuel deposition rates of montane and subalpine conifers in the central Sierra Nevada, California, USA. Forest Ecology and Management 259: 2122-2132 https://doi.org/10.1016/j.foreco. 2010.02.024.

van Wagtendonk, J.W., W.M. Sydoriak, and J.M. Bendict. 1998b. Heat content variation of Sierra Nevada conifers. International Journal of Wildland Fire 8: 147-158 https://doi.org/10.1071/WF9980147.

\section{Submit your manuscript to a SpringerOpen ${ }^{\circ}$ journal and benefit from:}

- Convenient online submission

- Rigorous peer review

- Open access: articles freely available online

High visibility within the field

- Retaining the copyright to your article

Submit your next manuscript at $\boldsymbol{\nabla}$ springeropen.com 